\title{
Effect of Water Logging Stress at Specific Growth Stages in Onion Crop
}

\author{
P.H. Ghodke , D.V. Shirsat, A. Thangasamy, V. Mahajan, \\ V.N. Salunkhe, Y. Khade and M. Singh \\ ICAR-Directorate of Onion and Garlic Research, Rajgurunagar, Pune-410505, \\ Maharashtra, India \\ *Corresponding author
}

\begin{tabular}{|l|}
\hline Ke y w or d s \\
$\begin{array}{l}\text { Onion, Water- } \\
\text { logging, Sensitive } \\
\text { growth stage }\end{array}$ \\
\hline Article Info \\
\hline $\begin{array}{l}\text { Accepted: } \\
\text { 26 December } 2017 \\
\text { Available Online: } \\
\text { 10 January } 2018\end{array}$ \\
\hline
\end{tabular}

Keywords

Onion, Waterlogging, Sensitive growth stage

Accepted:

26 December 2017

Available Onlin

A B S T R A C T

\begin{abstract}
Water-logging is one of the major abiotic stress that severely limits onion productivity world-wide. In onion, bulb size and yield are the economically important parameters that are getting seriously hampered due to frequent flooding events during Kharif season. An experiment was conducted under artificial waterlogging condition to identify the most sensitive growth stage for water logging stress in onion variety Bhima Super during Kharif 2017. The 45 days old seedlings were transplanted in plastic pots and the entire growth period of onion crop was divided into 11 different growth phases. Plants were subjected to water-logging condition created in pit for continuous 10 days during each growth phase and thereafter normal irrigation schedule was followed through-out the growth period. Data interpretation showed that the crop growth period from 20 to 90 days after transplanting (DAT) is found to be sensitive to water logging stress as the plants showed reduction in various morphological traits, survival rate, bulb quality traits (phenol, pyruvic acid, flavanoids, antioxidant activity, total soluble solids) and failed to produce marketable size bulbs. However, the growth period from 20-30 DAT (Bulb initiation stage) is found to be the most critical one as it failed to initiate the bulb formation with overall reduction in crop growth and quality. In contrast, the flooding during early vegetative stage (1-20 DAT) and towards the bulb maturity stage (90-110 DAT) was found to be less damaging as most of the plants are able to survive with better performance and able to produces marketable size bulbs. The study thus identified 20-30 DAT (Bulb initiation stage) is the most sensitive growth stage in onion crop for water-logging stress.
\end{abstract}

\section{Introduction}

Flooding is the major abiotic constraint affecting many parts of the world every year (Jackson and Colmer, 2005). It often occurs due to intense, erratic rainfall and gets severe due poor soil drainage consequently, affecting the crop yield and productivity. However, the intensity of waterlogging or soil flooding injury varies from crop to crop grown under different agro climatic zones. Plant architecture especially, the root system plays a significant role in determining the ability of a particular crop to sustain the severity of waterlogging stress. Plants with adventitious root system as seen in tomato (Ezin et al., 2010) and well developed aerenchyma tissues formation in stem and roots as noted in rice 
and wheat crop are able to tolerate the soil flooding for certain period (Herzog et al., 2016). Thus, under waterlogging condition root plays a significant role in order to save the crop under such environmental pressure.

Onion (Allium cepa L.), is an economically important vegetable crop cultivated throughout the world. It is a valuable crop not only in daily human diet but also as highest foreign exchange earner among the fruits and vegetables. World-wide, India ranks first in area (1.2 Million hectare) and second in production (19.4 Million tonnes in 2015), the first being China (Kumar et al., 2015; Laxmi et al., 2017). The productivity of onion in India is low i.e. 16.13 tons/ ha compared to other countries (Tripathi et al., 2017). The major reason for its low productivity is mainly the environmental constraints viz., biotic and abiotic stress. In India, onion is cultivated in three season Kharif, late-Kharif and Rabi contributing 20, 20 and $60 \%$ respectively. Although, Rabi harvest is the major contributor, Kharif onion play a significant role in fulfilling the consumers demand and price stabilizing thereby controlling the market year round. However, Kharif crop is highly at risk due to heavy and uncertain rainfall distribution pattern that lowers the bulb yield and productivity thereby leading to sudden price hike in market if the crop failed due to heavy rainfall for prolonged duration. Thus, intense rainfall leading to soil flooding seems to be the emerging threat for Kharif onion production.

Onion crop is highly sensitive to water logging stress due to its shallow root system. The maximum root penetration in onion is about $75 \mathrm{~cm}$ and high root density occurs in top soil layer of $18 \mathrm{~cm}$ (Drinkwater and Janes, 1955). This root growth habit of onion crop makes it highly prone to adverse affect of soil flooding stress mainly during Kharif season. The extent of damage due to heavy rains depends not only on the soil property, variety, intensity and duration of rainfall but mainly upon the crop growth stage that determine the yield and survival potential of a particular onion variety. Since the major part of the onion producing region are assumed to be strongly exposed to water logging and soil flooding in the future due to changing climatic scenario, development of technologies and varieties to cope with such stress conditions are of particular interest. Till date, research examining waterlogging stress inducible responses of onion has mainly focused on the application of plant growth regulators and degree of stress tolerance. However, proper knowledge of the effect of flooding/ waterlogging on the specific onion growth stage and its consequence is far behind. With this circumstance the present study was conducted to evaluate the effect of waterlogging stress at different growth stages in onion crop during Kharif season on plant survival, morphological, physiological, bulb yield and quality. The present study will further identify the most sensitive growth stage of onion crop for waterlogging stress so as to elaborate our understanding of complex mechanism involved in water logging tolerance in onion crop.

\section{Materials and Methods}

The study was carried out at ICAR-Directorate of Onion and Garlic Research, Pune, Maharashtra, India $\left(18.32^{0}\right.$ North latitude and $73.51^{0}$ East longitude, $553.8 \mathrm{~m}$ above mean sea level, annual rainfall $574 \mathrm{~mm}$ ) in Kharif 2017. The experiment was conducted by creating artificial water-logging condition in pit with onion variety Bhima Super in three replications each consisting of about 10 seedlings in plastic pot. The seedlings were raised in nursery with proper agronomic practices for 45 days and thereafter transplanted in plastic pots. All the necessary cultural practices like nursery management, 
fertilizer dose and plant protection measures were carried out as per recommendation in order to raise a good crop. The entire growth period of onion crop in Kharif season of 110 days after transplanting (DAT) was divided into 11 different growth phases (Table 1). Plants were subjected to water-logging condition for continuous 10 days for each growth phase and thereafter normal irrigation schedule was followed through-out the growth period.

The seedlings were monitored critically after the water-logging treatment for survival percentage and various physiological responses. The survival percentage was recorded after relieving the water logging treatment. The phenotypic observations like plant height, leaf length and leaf area was recorded from both control and stressed plants. For physiological traits like chlorophyll and antioxidant activity, leaf sampling $\left(4^{\text {th }}\right.$ leaf) was done immediately after the end of stress period whereas, biochemical traits like Phenol, Flavanoids, Pyruvic acid and TSS were evaluated from the bulb sample after harvest. Plants were harvested when the leaves turned yellow and neck fall occurred. The yield associated traits like number of bulbs, bulb weight and bulb size was estimated after the harvest. The bulb size viz. polar bulb diameter and equatorial bulb diameter was measured using electronic digital calliper. Bulbs were separated from the plants and graded to determine the bulb weight. Observations were recorded for all the parameters in replicates.

The chlorophyll content was estimated in $0.05 \mathrm{~g}(\mathrm{w})$ of leaf sample in $10 \mathrm{ml}(\mathrm{V})$ DMSO (Dimethyl Sulfoxide) by non-maceration method (Hiscox and Israelstam, 1979). Absorbance was recorded at 645 and $665 \mathrm{~nm}$ then total chlorophyll was calculated using formula of Arnon (1949). It is calculated as total chlorophyll $=\left(20.2 \times \mathrm{A}_{645}+8.02 \times \mathrm{A}_{663}\right)$ $\mathrm{x}$ Volume of extract $\mathrm{x}$ Weight of sample/1000. Phenol was measured by the method given by Bray et al., (1954). The antioxidant activity is determined by Ferric Reducing Antioxidant Power (FRAP) Assay method described by Benzie and Strain (1996). Pyruvic acid an important metabolic in onion bulb directly correlated with its pungency was estimated as per given by Randle and Bussard (1993) whereas, total flavanoids was determined by method given by Olivera (2008). Total Soluble Solids (TSS) was measured from bulbs after harvest by using refractometer and expressed in ${ }^{0} \mathrm{Brix}$ (Hanna instruments, USA).

\section{Results and Discussion}

Onion is an important vegetable crop cultivated worldwide for culinary purpose. In India, for the year round supply of this valuable commodity there is a need to focus more on the Kharif onion production technology. However, been a shallow rooted crop, it is found to be highly sensitive to flooding and unseasonal rainfall. The present work was conducted to determine the most sensitive growth stage in onion crop for water logging stress in order to develop certain technology and varieties for increasing Kharif onion production. Artificial water-logging condition was created in pit where, the seedlings in plastic pots were placed with the water level of $5 \mathrm{~cm}$ above the soil surface. The adverse affect of water-logging, reflected in terms of plant survival percentage was monitored daily after the beginning of flooding treatment throughout the crop growth stages. The survival percentage of seedlings was found to be low when water-logging stress was imposed 70-90 days after transplanting (DAT). In contrast, the flooding treatment during early vegetative stage i.e. 120 DAT and towards the bulb maturity stage i.e. 90-110 DAT was found to be less detrimental as most of the plants are able to survive and recovered after the stress 
treatment (Figure 1). The results are supported by the previous findings in pigeon pea crop where, water logging stress increases seedling mortality and reduces the chlorophyll content leading to chlorosis and senescence of leaves in most of the sensitive genotypes (Singh et al., 2016).

The effect of water-logging stress during the different crop growth phase on various phenotypic traits was evaluated at the end of stress treatment. Water logging stress adversely affects the overall plant architecture particularly, the plant height, leaf length and leaf area (Figure 2). The initial crop growth period from 1-20 DAT and towards bulb maturity stage (90-110 DAT) was found to be less sensitive to flooding stress as it maintained its morphological parameters that might contributes to its better performance under water-logging condition. The treatment T2 (10-20 DAT) was found to be significantly superior over control plants for growth performance like plant height and leaf length (Figure 2). The similar findings reported in tomato crop where, the response of various morphological, physiological and biochemical traits increasingly reduce as the water-logging stress progresses (Singh et al., 2017). The significant physiological parameter that are directly linked with the photosynthesis ability of plant and ultimately yield get seriously hampered due to flooding. The present study revealed that occurrence of water-logging stress during any of the crop growth stage severely reduces the leaf area thereby affecting bulb development and yield. However, the initial growth phase up to 20 DAT and towards bulb maturity (90-110 DAT) able to maintain its leaf area and photosynthetic ability irrespective of the water logging stress up to certain extent.

Another important photosynthesis contributing parameter viz. chlorophyll content found to be significantly lower when stress was imposed 20-30 DAT whereas, there was non-significant affect of flooding treatment on chlorophyll level in other growth stages (Figure 3). Previous findings in pigeon pea supports our result where, water-logging restricts the leaf growth by reducing the leaf area and accelerating the leaf senescence by reducing the total leaf chlorophyll content ultimately limiting the active photosynthesis process thus the yield however, information in this context is limited in onion crop (Kumutha et al., 2009, Yui et al., 2009 a, b).

Fig.1 Effect of waterlogging stress (10 days) at specific growth stage on survival percentage in onion crop

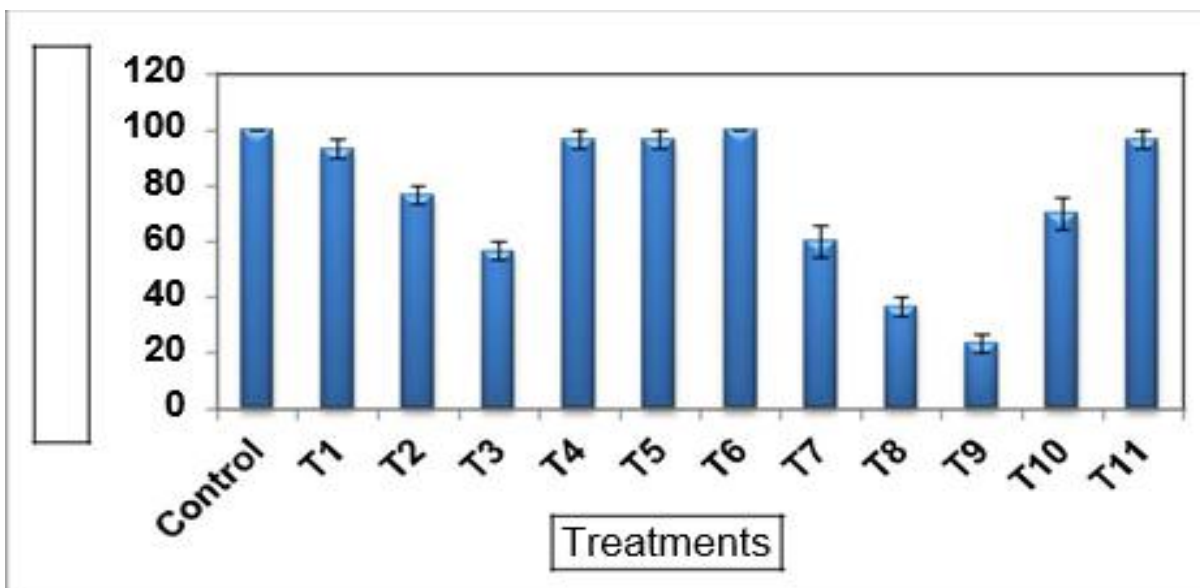

T1; 1-10 DAT, T2; 10-20 DAT, T3; 20-30 DAT, T4; 30-40 DAT, T5; 40-50 DAT; T6; 50-60 DAT, T7; 60-70 DAT, T8; 70-80 DAT, T9; 80-90 DAT, T10; 90-100 DAT; T11; 100-110 DAT, Control; Normal irrigation schedule 
Fig.2 Effect of waterlogging stress (10 days) at specific growth stage on morphological parameters in onion crop

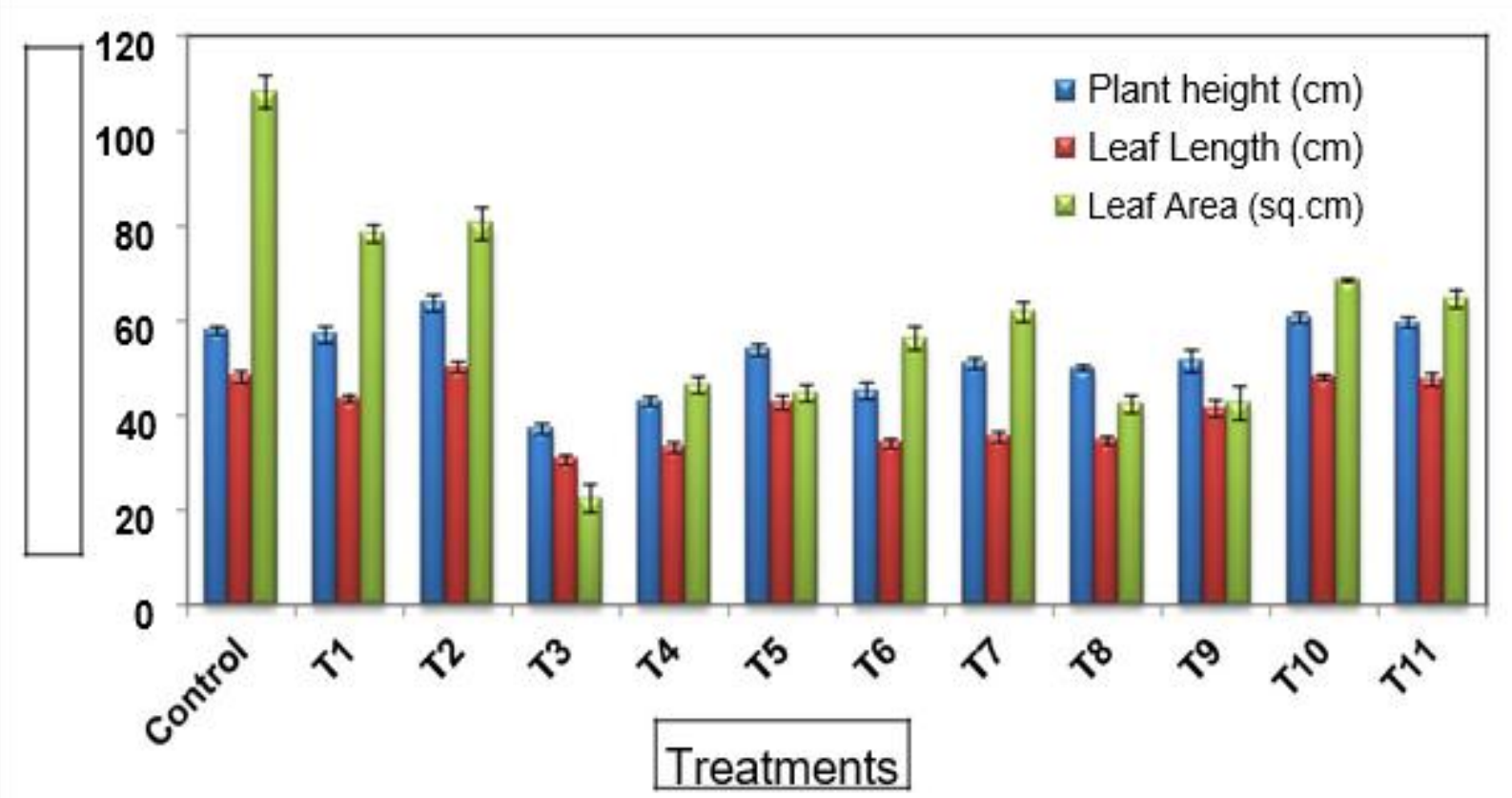

T1; 1-10 DAT, T2; 10-20 DAT, T3; 20-30 DAT, T4; 30-40 DAT, T5; 40-50 DAT; T6; 50-60 DAT, T7; 60-70 DAT, T8; 70-80 DAT, T9; 80-90 DAT, T10; 90-100 DAT; T11; 100-110 DAT, Control; Normal irrigation schedule

Fig.3 Effect of waterlogging stress (10 days) at specific growth stage on chlorophyll content in onion crop

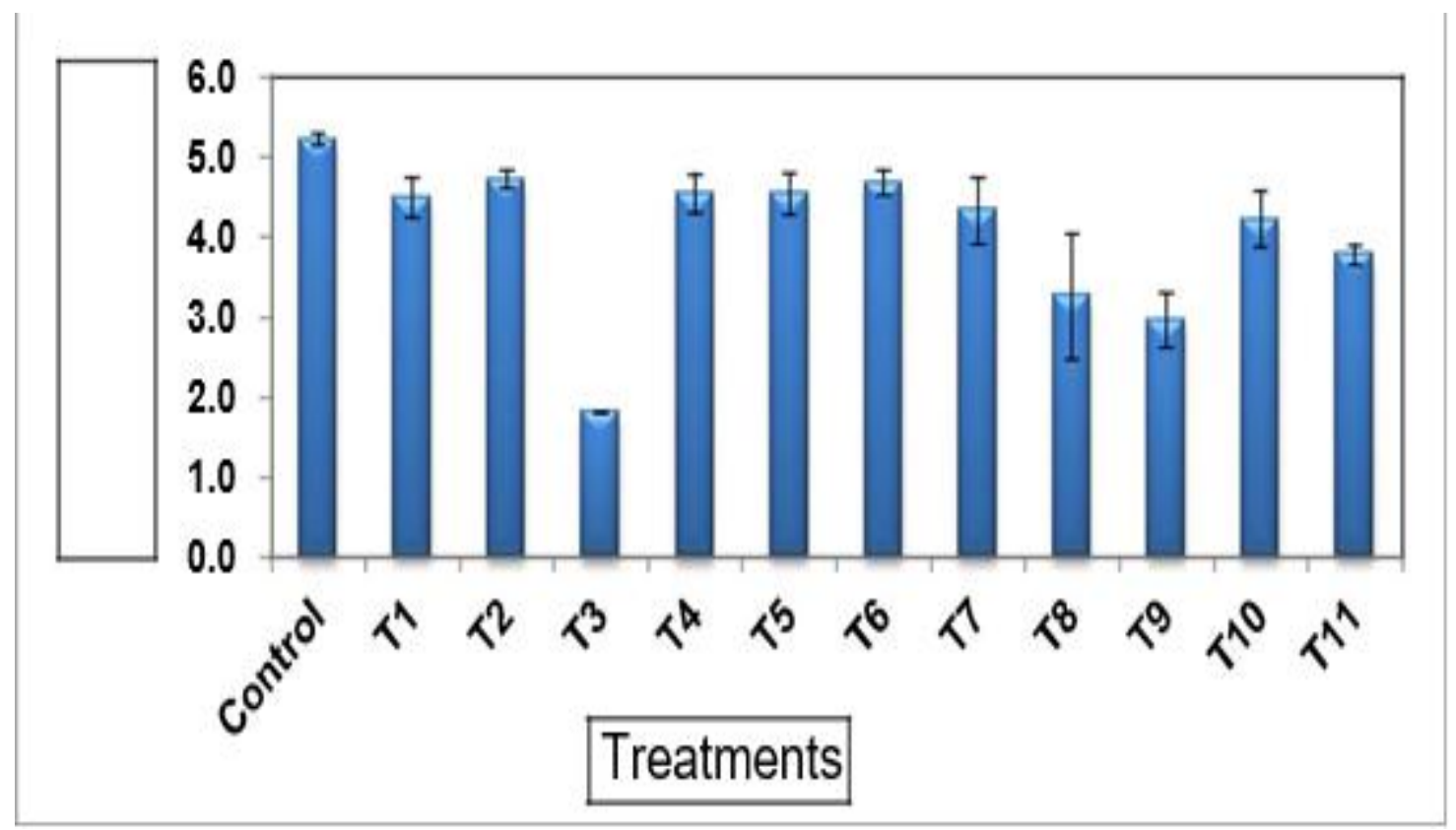

T1; 1-10 DAT, T2; 10-20 DAT, T3; 20-30 DAT, T4; 30-40 DAT, T5; 40-50 DAT; T6; 50-60 DAT, T7; 60-70 DAT, T8; 70-80 DAT, T9; 80-90 DAT, T10; 90-100 DAT; T11; 100-110 DAT, Control; Normal irrigation schedule 
Fig.4 Effect of waterlogging stress (10 days) at specific growth stage on biochemical parameters in onion crop

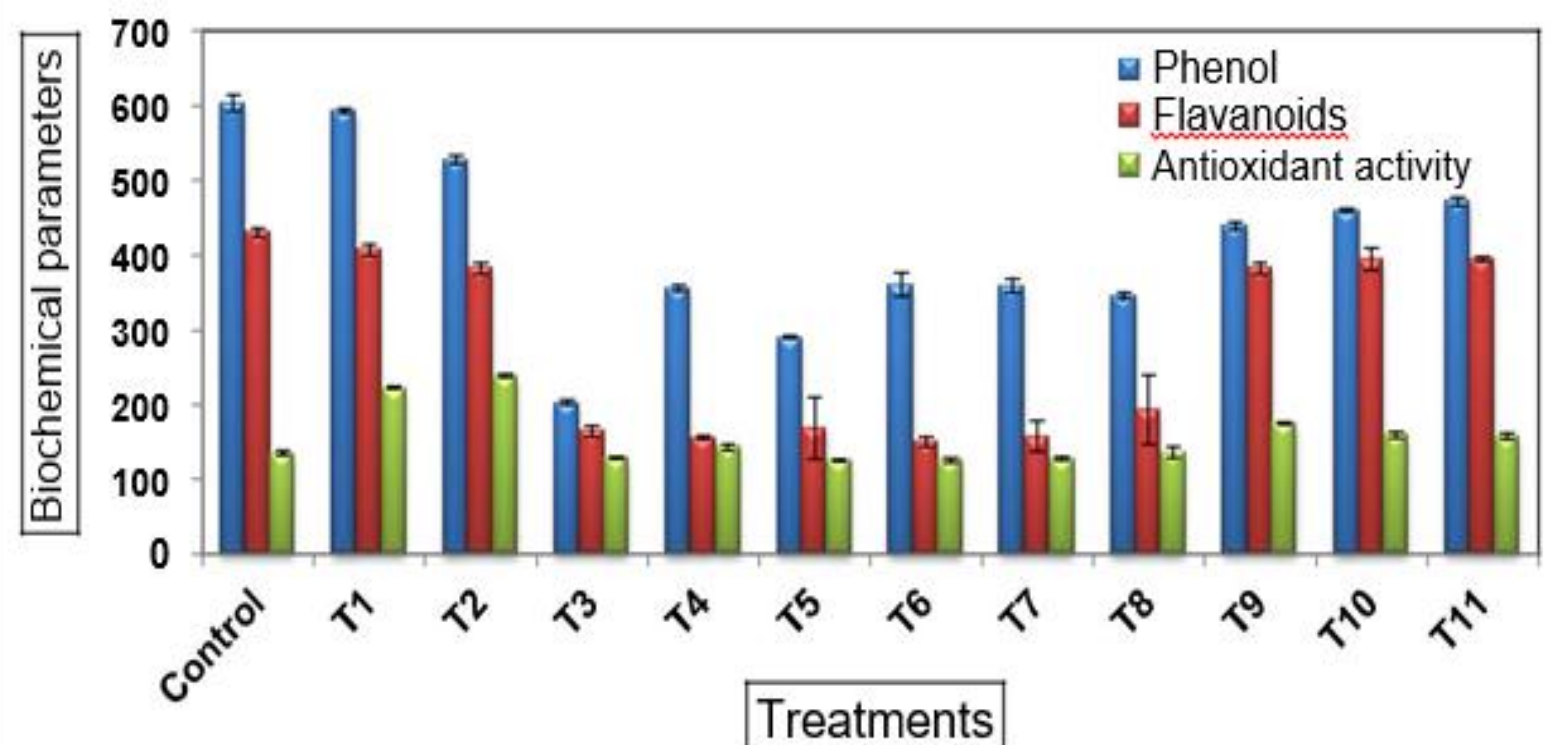

T1; 1-10 DAT, T2; 10-20 DAT, T3; 20-30 DAT, T4; 30-40 DAT, T5; 40-50 DAT; T6; 50-60 DAT, T7; 60-70 DAT, T8; 70-80 DAT, T9; 80-90 DAT, T10; 90-100 DAT; T11; 100-110 DAT, Control; Normal irrigation schedule

Fig.5 Effect of waterlogging stress (10 days) at specific growth stage on pyruvic acid content in onion crop

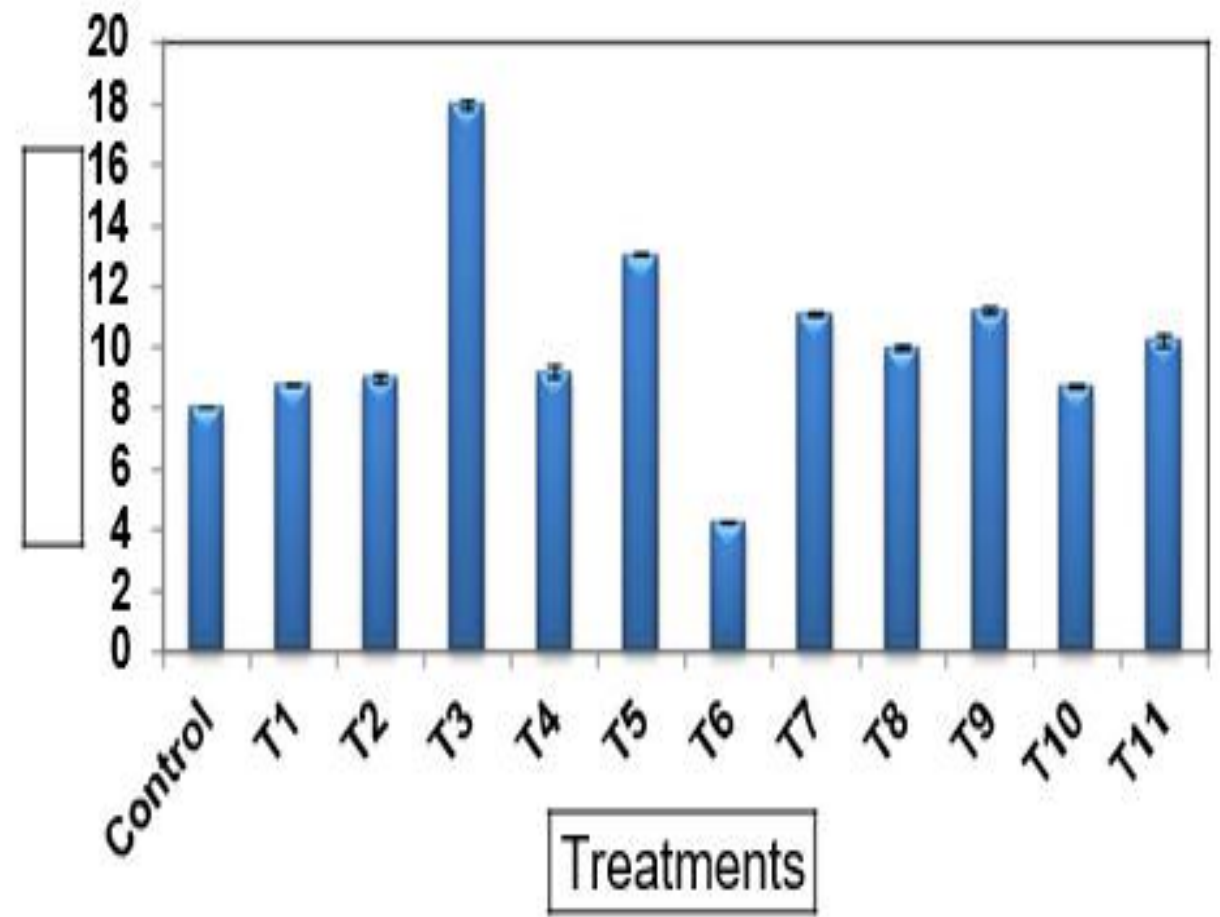

T1; 1-10 DAT, T2; 10-20 DAT, T3; 20-30 DAT, T4; 30-40 DAT, T5; 40-50 DAT; T6; 50-60 DAT, T7; 60-70 DAT, T8; 70-80 DAT, T9; 80-90 DAT, T10; 90-100 DAT; T11; 100-110 DAT, Control; Normal irrigation schedule 
Fig.6 Effect of waterlogging stress (10 days) at specific growth stage in onion variety Bhima Super

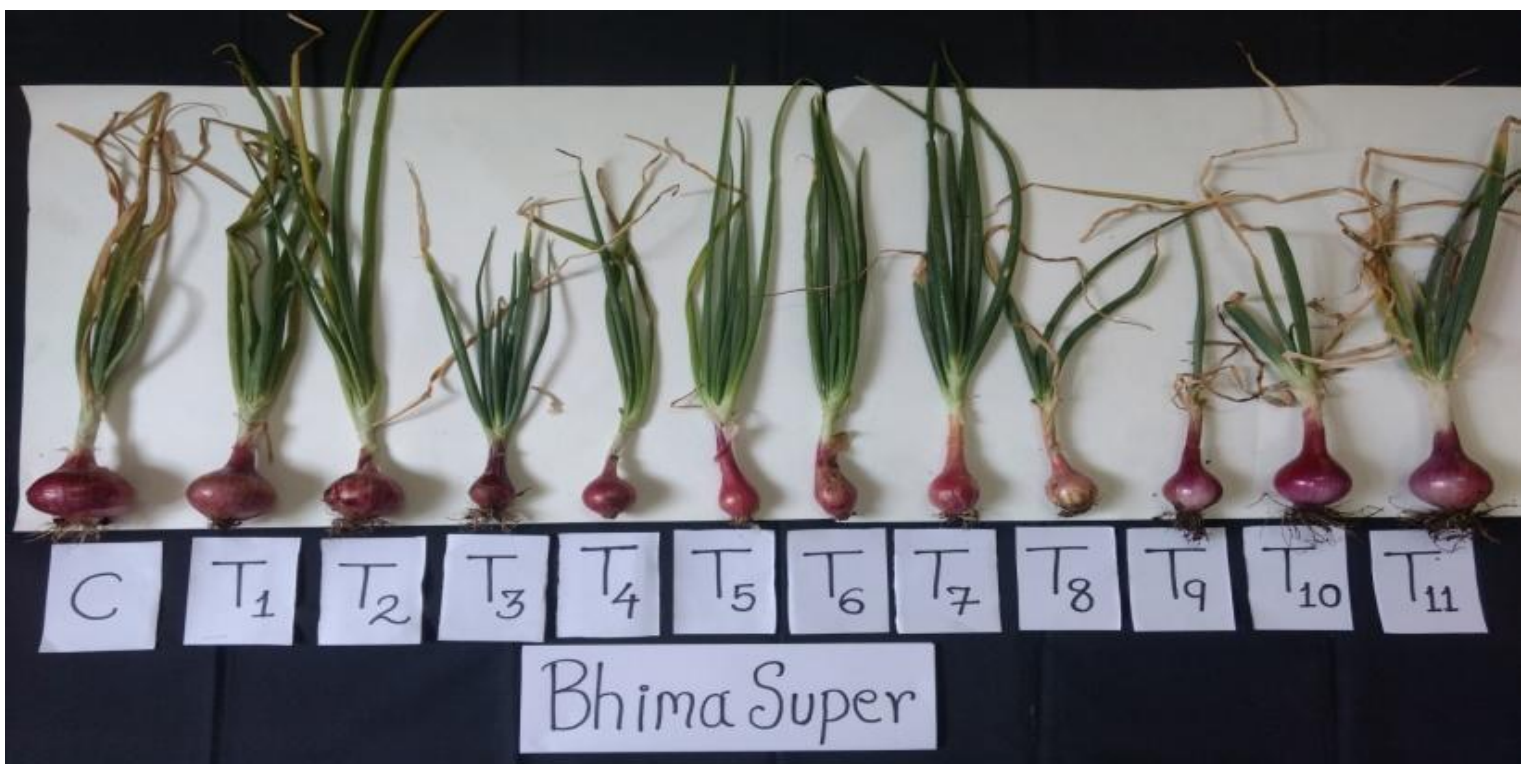

T1; 1-10 DAT, T2; 10-20 DAT, T3; 20-30 DAT, T4; 30-40 DAT, T5; 40-50 DAT; T6; 50-60 DAT, T7; 60-70 DAT, T8; 70-80 DAT, T9; 80-90 DAT, T10; 90-100 DAT; T11; 100-110 DAT, Control; Normal irrigation schedule

Table.1 Onion growth stages subjected to water-logging stress for 10 days

\begin{tabular}{|l|l|}
\hline Treatments & Onion crop growth stages and stress duration \\
\hline T1 & 1-10 DAT \\
\hline T2 & 10-20 DAT \\
\hline T3 & 20-30 DAT \\
\hline T4 & 30-40 DAT \\
\hline T5 & 40-50 DAT \\
\hline T6 & 50-60 DAT \\
\hline T7 & 60-70 DAT \\
\hline T8 & 70-80 DAT \\
\hline T9 & 80-90 DAT \\
\hline T10 & $90-100$ DAT \\
\hline T11 & 100-110 DAT \\
\hline C & Control \\
\hline
\end{tabular}


Table.2 Effect of waterlogging stress (10 days) at specific growth stage on bulb size, weight and TSS in onion variety Bhima Super

\begin{tabular}{|c|c|c|c|c|}
\hline Treatments & Bulb weight & Bulb Diam & nm) & $\operatorname{TSS}\left({ }^{0}\right.$ Brix) \\
\hline & (gm) & Polar size & Equatorial size & \\
\hline Control & 100.4 & 51.6 & 60.33 & 12.1 \\
\hline T1 & 84.6 & 57.1 & 56.18 & 10.5 \\
\hline $\mathbf{T} 2$ & 65.0 & 47.1 & 51.68 & 9.8 \\
\hline T3 & 21.1 & 35.1 & 28.52 & 9.1 \\
\hline $\mathbf{T 4}$ & 31.1 & 37.5 & 37.66 & 9.7 \\
\hline T5 & 21.4 & 47.2 & 28.69 & 10.6 \\
\hline T6 & 24.3 & 52.1 & 29.65 & 10.7 \\
\hline $\mathbf{T 7}$ & 32.9 & 49.1 & 35.92 & 7.2 \\
\hline T8 & 28.5 & 42.6 & 35.27 & 10.2 \\
\hline T9 & 38.3 & 45.4 & 39.57 & 8.1 \\
\hline T10 & 72.3 & 55.3 & 51.02 & 9.1 \\
\hline T11 & 76.2 & 51.5 & 51.35 & 9.1 \\
\hline CD $(5 \%)$ & 5.077 & 2.359 & 5.923 & 1.072 \\
\hline
\end{tabular}

T1; 1-10 DAT, T2; 10-20 DAT, T3; 20-30 DAT, T4; 30-40 DAT, T5; 40-50 DAT; T6; 50-60 DAT, T7; 60-70 DAT, T8; 70-80 DAT, T9; 80-90 DAT, T10; 90-100 DAT; T11; 100-110 DAT, Control; Normal irrigation schedule; Total Soluble Solids; TSS 
In onion, flavor and pungency an important biochemical trait responsible for its market value is contributed by various organosulphur and phenolic bioactive compounds (Perez-Gregorio et al., 2014). The unseasonal rainfall and soil flooding significantly influences the bioaccumulation of these valuable compounds in onion bulbs. The water-logging stress during the early bulb initiation followed by bulb maturity stage able to maintain its phenol and flavanoids content in bulbs as good as that found in bulbs from control plants (Figure 4). In contrast, plants subjected to water logging stress during 20-30 DAT recorded a drastic reduction in the above metabolites. Under flooding condition, burst in the production of reactive oxygen species (ROS) takes place that severely damages the overall crop metabolic processes however, plant can withstand such situation by inducing its antioxidant enzyme activity. The significantly higher antioxidant activity was recorded in stressed subjected plants as compared to control plants in response to water-logging however, early crop growth stage (1-20 DAT) responded superiorly as compared to other growth stages (Figure 4). The findings by Yiu et al., (2009 a, b) in onion crop are in accordance with the result where, exogenous application of certain phyto-hormones can protect the plant under flooding stress by accelerating the antioxidant enzyme activity to lessen the oxidative stress consequences.

Response of onion crop to drought stress revealed that the qualitative trait particularly, the phenol and pyruvic acid contributing to onion taste and flavor gets lowered under water deficit stress (Wakchaure et al., 2018). Our study evaluate the response of these metabolites to water logging stress and found that pyruvic acid induced throughout the crop growth stages except during 50-60 DAT in response to water-logging stress (Figure 5). These suggest that in contrast to the effect of drought stress, flooding recorded less effect on the bioaccumulation of this organo-sulphur compound in onion bulbs. In addition to the physiological and biochemical traits, the economically valuable traits i.e. bulb size and weight gets severely affected under soil flooding during Kharif and unseasonal rainfall during late- Kharif and Rabi season in the major onion growing region. The reduction in kharif production limits the onion bulb supply in market thus leading to sudden price hike. To address the challenge the number of bulbs formed, its size and weight were evaluated after imposing the water logging stress during the successive growth stages in onion in order to identify the most sensitive growth phase for water logging stress. The findings of the present study showed that water-logging stress during the bulb development stage (2080 DAT) failed to produce marketable size bulbs of good quality. Whereas, the early vegetative stage (1-20 DAT) and growth stage reflecting bulb maturity phase found to be less prone to flooding stress as the plants are able to produce bulbs of marketable size, weight and quality that are further found to be significantly at par with bulb from control plants (Table 2).

The parallel findings reported in tomato crop, where soil flooding significantly reduces the fruit weight and yield with fewer fruits (Ezin et al., 2010). Total Soluble Solids (TSS) an important trait responsible for the flavor in onion found to be higher irrespective of the stress treatment (Table 2). Our result are supported by the recent finding in tomato crop where water logging reduces the overall plant morphological growth, chlorophyll, increase the amount of ROS production leading to oxidative damage and reduces the fruit yield and quality thereby limiting its commercial production (Rasheed et al., 2017). Limited reports are available in growth stage specific response of onion crop to drought stress (Pelter et al., 2004) however, our finding 
clearly showed the growth stage specific response of onion crop to flooding stress. Briefly, the study demonstrate that the entire bulb development stage (20-80 DAT) found to be sensitive to water-logging stress however, the period of 20-30 DAT (Bulb initiation stage) is found to be highly sensitive as it failed to initiate the bulb formation and also on the basis of different traits that are been evaluated in the current study. The findings thus critically identify the waterlogging sensitive growth stage in onion crop that may help in elaborating our understanding of flooding tolerance mechanism in onion crop. Thus, our study may be used as an indicator, while developing the onion production technologies and varieties in order to increase the kharif onion production.

\section{References}

Arnon, D., 1949. Estimation of Total chlorophyll. Plant Physiol, 24: 1-15.

Benzie, I.F. and Strain, J.J., 1996. The ferric reducing ability of plasma (FRAP) as a measure of "antioxidant power": the FRAP assay. Analytical biochemistry, 239: 70-76.

Bray, H.G. and Thorpe, W.V. 1954. Analysis of phenolic compounds of interest in metabolism. Methods Biochem Anal., 1: 27-52.

Drinkwater, W.O. and B.E. Janes, 1955. Effects of irrigation and soil moisture on maturity, yield and storage of two onion hybrids. Proc. Amer. Soc. Hort. Sci., 66: 267-279.

Ezin, V., Pena, R.D.L. and Ahanchede, A., 2010. Flooding tolerance of tomato genotypes during vegetative and reproductive stages. Braz. J. Plant Physiol., 22: 131-142.

Herzog, M., Striker, G.G., Colmer, T.D. and Pedersen, O., 2016. Mechanisms of water logging tolerance in wheat-a review of root and shoot physiology. Plant Cell Environ, 39: 1068-1086.

Hiscox, J.T. and Israelstam, G.F., 1979. A method for the extraction of chlorophyll from leaf tissue without maceration. Can J Bot., 57: 1332-1334.

Jackson, M.B. and Colmer, T.D., 2005. Response and adaptation by plants to flooding stress. Ann. Bot., 96: 501-505.

Kumar, V., Neeraj, S.S. and Sagar, N.A., 2015. Post-harvest management of fungal diseases in onion-a review. Int. $J$. Curr. Microbiol. App. Sci., 4: 737-752.

Kumutha, D., Ezhilmathi, K., Sairam, R.K., Srivastava, G.C., Deshmukh, P.S. and Meena, R.C., 2009. Water logging induced oxidative stress and antioxidant activity in pigeon pea genotypes. Biol Plantarum., 53: 75-84.

Laxmi, S., Sen, C. and Singh, R., 2017. Profitability, potential and progress of organic onion production: Evidences from Nalanda district of Bihar. Economic Affairs, 62: 33.

Oliveira, I., Sousa, A., Ferreira, I. C., Bento, A., Estevinho, L., Pereira, J. A., 2008. Total phenols, antioxidant potential and antimicrobial activity of walnut (Juglans regia L.) green husks, Food Chemi Toxicol., 46: 2326-2331.

Pelter, G.Q., Mittelstadt, R., Leib, B.G. and Redulla, C.A., 2004. Effects of water stress at specific growth stages on onion bulb yield and quality. Agric Water Manag, 68: 107-115.

Perez-Gregorio, M.R., Regueiro, J., SimalGándara, J., Rodrigues, A.S. and Almeida, D.P.F., 2014. Increasing the added-value of onions as a source of antioxidant flavonoids: a critical review. Crit. Rev. Food Sci. Nutr., 54: 10501062.

Randle W M and Bussard M L., 1993. Streamlining onion pungency analysis. Hort Science., 28: 60.

Rasheed, R., Iqbal, M., Ashraf, M.A., 
Hussain, I., Shafiq, F., Yousaf, A. and Zaheer, A., 2017. Glycine betaine counteracts the inhibitory effects of water logging on growth, photosynthetic pigments, oxidative defence system, nutrient composition, and fruit quality in tomato. $J$ Hortic Sci Biotechnol, 1-7.

Singh, S., Grover, P., Kaur, J., Singh, I., Singh, P., Choudhary, O.P., Hingane, A.J., Sameer Kumar, C.V. and Saxena, K.B., 2016. Genetic Variability of Pigeon pea (Cajanus cajan (L.) Millsp.) for Water Logging and Salinity Tolerance under in vitro and in vivo Conditions. American Journal of Experimental Agriculture, 12: 01-13.

Singh, S.K., Singh, A.K. and Dwivedi, P., 2017. Modulating effect of salicylic acid in tomato plants in response to waterlogging stress. Int. J. Agric. Environ. Biotechnol, 10: 1-8

Tripathi, P.C., Sankar, V. and Lawande, K.E.,
2017, Micro irrigation in onion (Allium cepa) and garlic (A. sativum)-a review. Current Horticulture, 5(1): 3-14.

Wakchaure, G.C., Minhas, P.S., Meena, K.K., Singh, N.P., Hegade, P.M. and Sorty, A.M., 2018. Growth, bulb yield, water productivity and quality of onion (Allium cepa L.) as affected by deficit irrigation regimes and exogenous application of plant bio-regulators. Agric Water Manag, 199: 1-10.

Yiu, J.C., Juang, L.D., Fang, D.Y.T., Liu, C.W. and Wu, S.J., 2009a. Exogenous putrescine reduces flooding-induced oxidative damage by increasing the antioxidant properties of Welsh onion. Sci Hort., 120: 306-314.

Yiu, J.C., Liu, C.W., Fang, D.Y.T. and Lai, Y.S., 2009b. Waterlogging tolerance of Welsh onion (Allium fistulosum L.) enhanced by exogenous spermidine and spermine. Plant Physiol Biochem., 47: 710-716.

\section{How to cite this article:}

Ghodke, P.H., D.V. Shirsat, A. Thangasamy, V. Mahajan, V.N. Salunkhe, Y. Khade and Singh, M. 2018. Effect of Water Logging Stress at Specific Growth Stages in Onion Crop. Int.J.Curr.Microbiol.App.Sci. 7(01): 3438-3448. doi: https://doi.org/10.20546/ijcmas.2018.701.405 